\title{
EATING OUT IN POLAND: HISTORY, STATUS, PERSPECTIVES AND TRENDS
}

\author{
IWONA KOWALCZUK, ${ }^{1}$ EWA CZARNIECKA-SKUBINA ${ }^{2}$
}

\begin{tabular}{|c|c|}
\hline & $\begin{array}{l}\text { Warsaw University of Life Sciences } \\
{ }^{1} \text { e-mail: iwona_kowalczuk@sggw.pl } \\
{ }^{2} \text { e-mail: ewa_czarniecka_skubina@sggw.pl }\end{array}$ \\
\hline $\begin{array}{l}\text { RECEIVED } \\
\text { ACCEPTED }\end{array}$ & $\begin{array}{l}7 \text { March } 2015 \\
14 \text { July } 2015\end{array}$ \\
\hline $\begin{array}{l}\text { JEL } \\
\text { CLASSIFICATION }\end{array}$ & N73, E2, L81 \\
\hline KEYWORDS & foodservice sector, Poland, changes \\
\hline ABSTRACT & $\begin{array}{l}\text { The aim of the paper is to provide an overview on major changes that took place in the foodservice market in } \\
\text { Poland before and after the economic transition, to discuss the current state of the sector and identify directions } \\
\text { for further development. } \\
\text { The article presents consumer foodservice market trends in Poland and main trends conditioning its further } \\
\text { development and transformation. In Poland, after the economic transformation of } 1989 \text { significant quantitative } \\
\text { and qualitative changes in the services sector were observed, including foodservice industry. Most foodservice } \\
\text { outlets were privatized, there was a rise of new establishments and qualitative changes in their organization. } \\
\text { As a result the Polish foodservice market became similar to western markets. Demographic, socio-cultural } \\
\text { and economic trends which affected consumers' needs and changed their expectations towards market } \\
\text { offer had also a stimulatory effect on the foodservice market transformation. Now Polish foodservice market } \\
\text { is still growing, although at a weaker rate than in previous years. Strong demand favors this growth. Rapid } \\
\text { development of tourism, expansion of tourist accommodation and the development of business infrastructure } \\
\text { are driving also foodservice sector development. }\end{array}$ \\
\hline
\end{tabular}

\section{Introduction}

Catering service is one of the oldest types of service activities. Name "gastronomy" derives from the Greek (gaster - stomach, normos - right) and is interpreted as a kind of economic activity involving the conduct of open caterers, or the art of preparing and serving food based on the culinary expertise. Catering is also knowledge about 
products, their nutritional value of rational food preparation, composing meals, culinary traditions and customs and habits related to food.

According to Sala (2004) gastronomy is an organized economic activity, consisting in satisfying consumer needs through the sale of prepared meals and beverages, creating conditions for their consumption at the point of sale and delivering a variety of services to meet entertainment, relaxation and mental recuperation needs.

There are three basic functions performed by the gastronomy: manufacturing, services and trade. These functions are changing with the economic and social development and changes in consumer needs. Many authors (Tu et al., 2011; Alraub et al., 2012; Vincent, Tianming, 2012; Wang, 2012) stated, that the quality of food and services are the most important determinants of customer estimation of catering establishments and it is the most important to identify market trends and match to them the offer to satisfy the requirements of consumers.

The aim of the study was to analyze the changes in supply and demand for catering services in Poland in the years 1947-2013 and to identify current trends in consumer behavior and their impact on the development of the catering offer.

\section{Material and methods}

Secondary research was conducted, based on CSO data (Statistical Yearbooks, Household Budgets) and Euromonitor (Oksiński, 2012) and Eurostat, as well as the results of the studies connected with analyzed problem - GFK (Rosa-Wojnicka, 2012) and Kowalczuk (2012b). The last of these studies was conducted in 2011 on a nationwide, representative (quota sampling) sample of 1013 people over the age of 15 . For the evaluation of the collected material comparative method was applied.

\section{Results}

\section{Food service supply}

After the Second World War, in the period of the centrally planned economy, consumer foodservice in Poland belonged to the underdeveloped service sector. After 1947 private establishments were closed or seized by state-owned enterprises and cooperatives. By 1989 primarily socialized catering developed: state-owned and co-operative food services and, to a very small extent, private companies (Table 1).

Table 1. Number of consumer foodservice establishments in Poland until 1988

\begin{tabular}{lrrrrrrrr}
\hline \multirow{2}{*}{ Specification } & \multicolumn{7}{c}{ Years } \\
\cline { 2 - 9 } & 1950 & 1955 & 1960 & 1970 & 1975 & 1980 & 1985 & 1988 \\
\hline $\begin{array}{l}\text { Total state } \\
\quad \text { owned enterprises }\end{array}$ & 6,613 & 7,165 & 10,235 & 14,309 & 19,639 & 25,048 & 24,751 & 26,558 \\
$\quad$ and cooperatives & & & & & & & & \\
Private companies & 3,669 & 6,686 & 9,117 & 12,844 & 17,373 & 21,004 & 18,365 & 17,870 \\
$\quad \begin{array}{l}\text { Total canteens } \\
\quad \text { and employees buffets }\end{array}$ & 2,944 & 479 & 1,118 & 1,465 & 2,266 & 4,044 & 6,386 & 8,688 \\
\hline
\end{tabular}

* consumer foodservice establishments excluding canteens and buffets.

Source: own study based on Statistical Yearbook of Poland (1960-1989). 
The growth in the first years of the post-war was oriented on increasing the number of previously closed foodservice facilities, mainly canteens and buffets addressed to a particular group of consumers. Milk bars, eateries, restorative meals catering for employees of large factories and restaurants in villages were expanding.

During this period, next to the mentioned premises performed coffee bars, fruit bars, cake shops, bars with alcohol, cafeterias, pastry shops, tea rooms and, since the 60 s, clubs-restaurants designed for specific professional groups (doctors, economists, actors) started to develop. In the 70 s, about $30 \%$ of all food service outlets were casted into private business. In the 80 s, especially in bigger cities, the so-called 'small catering' appeared, in other words outlets offering simple dishes in small premises, detached stalls and caravans. Food choice was limited and the quality was leaving much to be desired. The highest level of service at this time was offered by hotels and few restaurants (Czarniecka-Skubina, 2008). It should be noted that, during this period, running a business was very annoying. There were problems with the supply, rationing of goods, private establishments were hindered by various state inspections.

The supply of food services immediately after the war was insignificant, in the following years new outlets were emerging, which resulted in a systematic decrease of number of persons occurring per consumer site - from 121 persons in 1950, 56 in 1960, 36 in 1970 up to 35 in 1988. This did not satisfy consumer needs and outside the foodservice units long queues formed awaiting for a vacant space and the possibility to eat (Statistical Yearbook, 1960-1989).

Foodservice has gone through major changes and since the 90 s of the last century has undergone a remarkable transformation. This refers to the number of outlets, types, forms of activities, as well as to the revenue size and structure. The Law of 1988 on conducting business and its legislation contributed the most to this process. As a result of economic changes many new types of catering services previously unknown emerged. The Polish foodservice market became similar to the world foodservice industry.

In 90s fast food and international food chains, which appeared in Poland in 1992 were a novelty on the Polish market (McDonald's, Burger King, Pizza Hut). First casual restaurants were opened by Sphinx Poland. Since 1993, with the entry into the Polish market of such companies as Eurest and Sodexho, various forms of catering began to develop. Currently, the organization of nutrition in schools, kindergartens, hospitals, and army is entrusted to catering operators. In the late 90 s, first sushi bars began to appear.

Foodservice sector privatization had a significant impact on the dynamic changes. In 1989, private outlets accounted for about $15 \%$ of their total number, and ten years later for $96 \%$. Currently catering industry is almost entirely privately held (98\% in 2013), which leads mainly to a broad choice and more efficient management (Statistical Yearbook of the Republic of Poland, 1990-2014).

During the 1990-2004 period the foodservice industry saw a significant growth and the highest growth of over $15 \%$ was reported in 2000 . As of 2005 , the number of consumers food service units visibly declined - in 2013 up to 67693 outlets which is a decline by more than 26\% compared to 2005 (Table 2). In the 90 s the simplest forms of catering, mainly bar and catering points, performed best. In 2000-2004 all types of food services were rapidly expanding, while in 2005-2013 only restaurants recorded the largest growth. Currently, foodservice market is still dominated by bars (37\%) and food stands (32\%), but their share is steadily decreasing in favor of restaurants $(25 \%)$ (Table 2). 
Table 2. Changes in the number (in \%) of consumer foodservice establishments in 1989-2013

\begin{tabular}{|c|c|c|c|c|c|c|c|}
\hline \multirow{2}{*}{ Specification } & \multicolumn{7}{|c|}{ Years } \\
\hline & 1989 & 1995 & 2000 & 2005 & 2010 & 2012 & 2013 \\
\hline \multirow{2}{*}{ Restaurants } & \multirow{6}{*}{$\begin{array}{c}19,556 \\
(63.0)\end{array}$} & 4,857 & 8,519 & 9,716 & 13,874 & 16,478 & 16,936 \\
\hline & & $(8.0)$ & (10.1) & $(10.6)$ & (19.4) & $(23.9)$ & (25) \\
\hline Bars* & & 23,493 & 36,436 & 40,834 & 28,696 & 25,885 & 25,195 \\
\hline Dals & & $(38.5)$ & $(43.2)$ & $(44.4)$ & $(40.0)$ & $(37.6)$ & (37.2) \\
\hline \multirow{2}{*}{ Food stands } & & 28,680 & 32,377 & 34,572 & 24,676 & 22,120 & 21,447 \\
\hline & & $(47.1)$ & $(38.4)$ & $(37.5)$ & $(34.4)$ & $(32.1)$ & $(31.7)$ \\
\hline \multirow{2}{*}{ Canteens } & 11,478 & 3,815 & 7,010 & 6,950 & 4,423 & 4,304 & 4,15 \\
\hline & $(37.0)$ & (6.3) & $(8.3)$ & $(7.5)$ & $(6.2)$ & $(6.2)$ & $(6.1)$ \\
\hline Total (100) & 31,034 & 60,845 & 84,342 & 92,072 & 71,679 & 68,787 & 67,693 \\
\hline
\end{tabular}

* bars: eateries, regular bars, fast food, snack bars, milk bars, bistros, cafes, tea rooms, pubs.

Source: Statistical Yearbook of the Republic of Poland (1990-2014).

The forecast period of 2013-2016 is expected to show a growth of all types of outlets, and canteens will boom only in 2016 (Oksiński, 2012).

Increasing competition in the foodservice market in Poland forces players to introduce more innovative and consumer oriented offers. Modern ways of communication with consumers are used, the Internet being a popular tool with access to such channels as outlets' websites, internet forums on nutrition and social networks. Various outlets offer happy hours, "all you can drink" or "next meal for free" in order to retain their consumers. Loyalty programs are gaining in popularity, and some of them include more offers in which catering brand is just one of many partners.

The financial condition of the foodservice sector is at a fairly good level. Revenues per 1 outlet amounted to 380,2 thousand PLN in 2013, which is an increase compared to 2012 by approximately $20 \%$. However, given a significant increase in operating costs it is not the prosperity of this service segment. It should be noted that the revenue growth comes not so much from the growing number of clients, but rather as a result of price increases.

The main sources of revenue from foodservice activity in 2013 came from catering production $(72.7 \%)$ and spirits and tobacco sales (16\%). Commodities sales (8.5\%) and other service activities were less important (3.0\%). Analyzing changes in the income structure one can observe systematic revenue growth from foodservice production (by 29 percentage points in 1995-2013) and a decrease in other areas of activity (Table 3).

Table 3. Changes in revenues from consumer foodservice activities in 1995-2013

\begin{tabular}{lrrrrrr}
\hline \multirow{2}{*}{ Specification } & \multicolumn{7}{c}{ Years* $^{*}$} \\
\cline { 2 - 7 } & \multicolumn{1}{c}{1995} & \multicolumn{1}{c}{2000} & \multicolumn{1}{c}{2005} & 2010 & \multicolumn{1}{c}{2012} & 2013 \\
\hline Total (in mIn PLN) & $7,027.0$ & $15,381.0$ & $17,681.0$ & $21,683.0$ & $24,868.0$ & $25,701.0$ \\
Revenue per 1 outlet (in PLN) & 115.5 & 182.4 & 192.0 & 307.1 & 317.4 & 380.2 \\
\hline & \multicolumn{1}{c}{ Revenue structure (\%) } & & & \\
\hline From sales of trade commodities & 18.9 & 17.4 & 14.6 & 8.7 & 8.7 & 9.0 \\
From sales of alcoholic beverages and tobacco & 35.0 & 27.9 & 27.5 & 19.3 & 18.5 & 16.0 \\
From catering production & 43.7 & 50.3 & 54.6 & 69.3 & 71.5 & 72.7 \\
From other activity & 2.4 & 4.4 & 3.8 & 2.8 & 2.3 & 2.3 \\
\hline
\end{tabular}

* lack of data for 1989.

Source: Statistical Yearbook of the Republic of Poland (2000-2014). 
Different data on the financial condition of Polish food service industry is given by Euromonitor International, according to which in last years, the sector has seen a tremendous sales growth, but it concerned mainly chain facilities, representing approximately $16 \%$ of all operating on the Polish market outlets. The growth was also noticed in catering establishments located in shopping malls. The best financial result in 2011 was recorded by restaurants (growth by $5.3 \%$ as compared to the previous year), just behind came the fast food sector (up 6.3\%), followed by cafes (a growth of 5.2\%). The most spectacular growth in sales was noticed in the 'home delivery/ takeaway' sector (7.6\%). According to forecasts, by 2016 all forms of catering business will increase sales, and the most spectacular growth in turnover is expected in fast food (40.5\% compared to 2011$)$, home delivery $(38 \%)$, pizzerias $(36 \%)$ and restaurants (35\%) subsectors (Table 4), (Oksiński, 2012).

Table 4. Value sales in consumer foodservice in Poland, in PLN - state and outlook

\begin{tabular}{lrrrrr}
\hline \multicolumn{1}{c}{ Specification } & \multicolumn{5}{c}{ Years } \\
\cline { 2 - 6 } & \multicolumn{1}{c}{2008} & 2009 & 2010 & \multicolumn{1}{c}{2011} & 2016 \\
\hline Home delivery/ Take away & 179.5 & 186.4 & 197.2 & 212.2 & 293.8 \\
Cafe/ Bars & $7,697.1$ & $7,442.7$ & $6,870.6$ & $7,224.8$ & $9,295.5$ \\
Restaurants with waiter services & $9,095.1$ & $8,091.5$ & $7,807.3$ & $8,222.3$ & $11,136.8$ \\
Fast Food & $5,716.2$ & $6,121.8$ & $6,351.9$ & $6,752.2$ & $9,489.3$ \\
Self-service canteens/ Cafeterias & $3,996.7$ & $3,962.1$ & $3,898.5$ & $3,786.6$ & $4,557.7$ \\
Street stalls/Kiosks & $1,824.8$ & $1,948.8$ & $2,032.1$ & $2,100.0$ & $2,547.3$ \\
Pizzerias & $2,519.4$ & $2,471.8$ & $2,501.1$ & $2,650.1$ & $3,623.8$ \\
\hline
\end{tabular}

Source: Oksiński (2012).

Other conclusions on the future of the Polish foodservice industry result from Polish restaurateurs survey. More than $3 / 4$ of restaurateurs express pessimistic view on the development of the industry arguing that the situation is getting more difficult, the economic growth slowed down, prices and costs are rising, competition is growing and the demand is decreasing (Rosa-Wojnicka, 2012).

\section{Food services demand}

Growing demand is the main driver of changes in the foodservice industry. It determines both the scale and directions. The research shows, that about $50 \%$ of Poles benefit from catering services (Kowalczuk, 2012b) and, according to GFK data, in 2005-2008 the percentage of customers has been growing steadily. In 2008, there was a drop of 5 percentage points, a rise to 52\% within the next 2 years and a decline in 2012 to $46 \%$ (Rosa-Wojnicka, 2012).

The growing demand for catering services is closely linked to rising household expenditures on such services (Levytska, Kowrygo, 2007). In 2013, an average Pole spent 26.2 PLN per month (about \$8) on eating out, which accounted for $8.5 \%$ of their total food budget and $2.5 \%$ of the total expenditures. Compared to 2000 , the amount of money allocated on catering services increased more than three times, their share in food spendings and total expenditure doubled.

Compared to other EU countries the share of spendings on catering services in total expenditures of Polish households is decidedly low - for 27 UE countries - average is 6.9\%, but in Spain - 14.8\%, Ireland - 11.8\%, Greece $-10.4 \%$. This indicates a low susceptibility of Poles to eat out of home (Eurostat New Release..., 2011). 
In comparison with other socio-professional groups, representatives of the wealthiest social groups stand out in terms of the amount of money spent on food services: workers on non-manual positions and self-employed (both about 43 PLN in 2013). In other social groups in 2013 was less: workers on manual positions - 18 PLN/ person, farmers - 12 PLN; retirees and pensioners - 16 PLN (Households Budget Survey 2001... 2014). Compare with previous years, the same dependence in average monthly expenditure was observed, but lower amount. The size of the household affects the level of expenditure on food services. Spendings are by far the highest in 1 person households (average monthly expenditure 63 PLN in 2013) and decrease as the number of members in the household grows (2 person households - 32 PLN; 3 - 27 PLN; 4 - 23 PLN; 5 -15 PLN; 6 - 11 PLN), which undoubtedly relates to a low prosperity of larger households, as well as to the fact that largest households are located in rural areas, where the access to catering facilities is limited and not very popular (Households Budget Survey, 2001-2014).

Survey conducted by Kowalczuk (2012b) indicated that an average Pole visits foodservice outlets once a month, slightly more often men and far more often young people, those with middle and higher income. More commonly from food services benefit people with secondary and higher education, including school and university students and white-collar workers. It is also more common in large cities. Similar consumer profile of catering services was identified however the average frequency of eating out ranged several times a year. Findings from the mentioned survey show that restaurants (61.5\%), fast food (44.4\%), bars and pubs (41.2\%), cafeterias (36.9\%) and cake shops (31.6\%) are the most visited food service outlets in Poland.

The main reasons for the use of catering services are the taste of dishes, reasonable prices, convenience and time saving, while the main barrier is the lack of money. Consumers tend to spend on one visit in a catering outlet about 26 PLN per person, and this amount largely depends on the income level, as well as age, education and place of residence. The reason for the occasional use of catering services bases also on the common Polish belief, that home-cooked meals are healthier.

Social gatherings and family celebrations promote visits in restaurants, which confirms the growing tendency of Poles of bringing social life outside home. About one-third of respondents benefit from foodservice while shopping, to eat something during the day and during a trip. Regular consumption in premises during work breaks was declared by one fifth of respondents, and the use of food services during business travels and business meetings by about $10 \%$ of the respondents.

The analysis of consumer preferences regarding types of cuisine and dishes allows to ascertain the conclusion that the most popular are Polish cuisine and, although to a lesser extent, Italian cuisine. Younger respondents are also open to consume dishes from other countries. Meat dishes and hot snacks are the most preferred, cold snacks and vegetarian dishes are less popular.

\section{Consumption trends and its consequences on the foodservice market}

In Poland in recent years, demographic, economic and socio-cultural changes are observed which significantly affect consumers expectations toward foodservice (Table 5). 
Table 5. Impact of selected trends on foodservice sector development

\begin{tabular}{|c|c|c|}
\hline Areas of changes & Trends & Implication for foodservice sector \\
\hline Demographic changes & $\begin{array}{l}\text { Growth of } 1-2 \text { members households. } \\
\text { Growing share of older people in the } \\
\text { population. }\end{array}$ & $\begin{array}{l}\text { Single tables, development of entertainment offer; culinary offer taking into } \\
\text { account dietary needs of the elderly, consulting. }\end{array}$ \\
\hline Economic changes & $\begin{array}{l}\text { Households income growth. } \\
\text { Households income polarization. }\end{array}$ & $\begin{array}{l}\text { Premises with high standards of services (premium), price promotions } \\
\text { (happy hours), diversification of outlets in terms of price and offer (traditional } \\
\text { and casual dining type), outlets ('All You Can Eat'). }\end{array}$ \\
\hline $\begin{array}{l}\text { Consumers knowledge } \\
\text { growth }\end{array}$ & $\begin{array}{l}\text { Growing education and increasing } \\
\quad \text { awareness on nutrition. } \\
\text { Increasing ecological awareness. } \\
\text { Greater access to the information } \\
\quad \text { (Internet). } \\
\text { Development of IT technologies. }\end{array}$ & $\begin{array}{l}\text { Food safety systems and factory quality food control (HACCP), nutrition } \\
\text { claims in menus, premises serving Bio and organic food, water consumption, } \\
\text { electricity, detergents, ect. decrease (ISO } 14001 \text { systems), use of Internet } \\
\text { in marketing communication (webpages, e-mailing, social networking, } \\
\text { blogs), use of computer programs (settlements, loyalty programs), } \\
\text { communication with customers (sms, mms). }\end{array}$ \\
\hline Lifestyle and eating habits & $\begin{array}{l}\text { Fashion for healthy lifestyle. } \\
\text { Changes in diet. } \\
\text { Looking for home meals substitutes. } \\
\text { Changes in time structure, a faster } \\
\quad \text { pace of life. } \\
\text { Spending free time in Shopping Mall. } \\
\text { Growth of women professional activity } \\
\text { and associated with this family out } \\
\text { of home consumption. } \\
\text { Increased tourist and business } \\
\text { population mobility. } \\
\text { Individualism, focus on own needs } \\
\text { and pleasure, hedonistic behavior. }\end{array}$ & $\begin{array}{l}\text { Premises meeting dietary preferences, including health oriented food (slow } \\
\text { food, vegetarian, diet, salad bars), premises offering traditional polish } \\
\text { dishes (e.g. creperies, dumpling), development of fast food, fast casual } \\
\text { and cheapeat entertainment, development of premises offering lunches } \\
\text { (snack facilities, sandwich shops, food trucks), development of dining offer } \\
\text { in shopping centers (food court) and exhibition halls, higher availability } \\
\text { of catering services, development of the takeaway offer, social catering } \\
\text { and office catering, development of hotel foodservice, roadside (on petrol } \\
\text { stations), railway station, premises serving ethnic cuisines, fusion and } \\
\text { molecular cuisine, new types of coffee houses (mobile, cafe-clubs, library- } \\
\text { cafes), places opened to culinary experiments (mood food, BFY food) } \\
\text { and beyond (ice bars, 'Dinning in the Dark'), individualization of customer } \\
\text { relationship. }\end{array}$ \\
\hline
\end{tabular}

Source: own study.

In the context of multi-directional changes in the characteristic of the modern Polish consumer three main trends important from the foodservice industry perspectives can be defined:

- 'health and safety' manifested by growing importance of product origins, quality of the offer, meals nutritional value (choice of raw materials and production processes) and their dietetic aspects (diets eliminating selected components, vegetarian diet and its variants) as well as growing knowledge expectations towards service staff on nutritional meals values,

- 'convenience' characterized by a high demand for 'fast food' and 'fast casual' offer, growing importance of the foodservice location, increasing demand for catering services,

- 'pleasure and experience-seeking', expressed by growing interest in ethnic cuisines, increased attention to interiors design and courses composition, individualization of consumption, increased interest in culinary experiments (ugly food, mood food, Better for You food, molecular cuisine), search of new, outstanding proposals within the frames of additional services (Kowalczuk, 2012a).

\section{Conclusions}

The presented information confirm the continuous development of foodservice market in Poland. Supply data shows that the most dynamic growth comes from restaurants and primary and still growing income share in foodservice comes from catering production. Data on the demand proves that expenses on catering services still 
dependent on the income level, and rising Poles incomes brings hope for consumer foodservice. Research findings on consumer expectations indicate large differentiation of consumer preferences, what enhances the extension of the catering offer and at the same time the improvement of quality standards. Requirements and barriers to the development of the foodservice market are presented in the form of a SWOT analysis in Table 6.

Table 6. SWOT analysis of foodservice market in Poland

\section{STRENGHTS}

High flexibility of operation (especially small and medium enterprises). Ability to respond quickly to market changes and consumers' needs.

Good reputation of Polish cuisine, useful while creating business service offer Interesting and diversified offer Significant growth rate.

\section{(ack financial resources.}

Lack of financial resources.

High operating costs, high prices.

Poor services because of lack of highly qualified staff.

Lack of expertise of managerial staff in organization, management and marketing.

Poor awareness of consumers' needs Lack of knowledge of customer service techniques.

Poor promotion of services.

OPPORTUNITIES

Demographic, economic, and social changes stimulating the demand for foodservices.

Large market of potential consumers Rapid development of tourism Development of business infrastructure.

Increasing interest in Polish cuisine Possibility of using EU funds

Government programs to support the development of small and medium-sized enterprises.

Relatively cheap labor costs.

Development of franchising systems Development of shopping malls.

\section{Rising operating costs (rent, utilities, salaries).}

Prospect of Value Added Tax increase Stringent health rules.

High cost of credit and growing financial requirements towards potential borrowers.

Increasing competition from multinational corporations.

Strong Poles home consumption habits.

Source: own elaboration.

Under-investment is the weakness of the foodservice industry. Lack of financial resources, particularly apparent in small and medium-sized enterprises results in low equipment standard, hygiene level, technological advancement. Low wages offered by the foodservice sector do not contribute to the achievement of high standards of service, which affects consumer's dissatisfaction. Foodservice staff lacks of professional knowledge in management and marketing, which weakens Polish companies competitive position compared to big internationals.

The demand growth is the main opportunity for native foodservice market. Polish consumers are receptive to the offer and in favorable economic situation will certainly take advantage of it. Also, cultural and socio-professional changes foster interest in out of home consumption. Moreover, a study by Gherbii (2013), confirms the demand conditions for the development of catering services. The development of gastronomy is supported by a dynamic development of tourism (both domestic and foreign). According to Meyer (2008), tourists, to meet their needs in travel, spend the funds supporting the development of sectors related to tourism, including gastronomy. The role of tourism in the development of the food service market is also highlighted by Masłowski (2001: 9). A particularly large impact of this factor is visible in the cities attractive to tourists or business.

Many economists expect the second wave of the crisis to be the main threat for the catering business. The crisis in the foodservice industry, as in other areas, so-called domestic services, is a simple result of consumers' lack of interest in offered services. This decrease results mostly from the deterioration of consumers' financial situation. According to statistics, wages are rising, but in recent times it was rather a symbolic growth offset by a significant 
inflation, weakening the economic condition of Polish households. In an unstable financial situation consumers obviously give up services that can be substituted by means of so-called self-service. According to the so-called 'bolt effect', directly after economic deterioration people try to maintain their previous level of consumption using accumulated savings or living on credit. Consumers start reducing expenses about a half to one year later. The so called 'bolt effect' seems to explain Polish consumers' lack of response to the first phase of the crisis.

The threat to native foodservice market comes also from increasing competition of international food chains and low financial and organizational potential of native enterprises. Competitive advantage in this situation should be built on external sources of funding (although the acquisition of funds is not an easy task), as well as on a better understanding of key demand drivers and increased flexibility of action.

\section{References}

Alraub, A.S.A., Alsaleem, A.S.M. \& Daoud, A.A. (2012). Service quality and its impact on customer satisfaction tourist restaurants (a field study on the tourist restaurants/amman). Interdisciplinary Journal of Contemporary Research in Business, 4 (1): 364-368.

Czarniecka-Skubina, E. (2008). Tradycje i nowe trendy w polskiej gastronomii. Rocznik Naukowy Wyższej Szkoły Turystyki i Rekreacji, im. M. Orłowicza w Warszawie. 1 (7): 142-149.

Eurostat New Release: statistics on the food chain. From farm to fork. Stat/11/93, 22.06. 2011.

Gherbii, E. (2013). Conditions of food service enterprises development. Marketing and Market, 4: 29-35.

Heung, V.C.S. \& Gu, T. (2012). Influence of restaurant atmospherics on patron satisfaction and behavioral intentions. International Journal of Hospitality Management, 31 (4): 1167-1177.

Budżety Gospodarstw Domowych (2001-2014). Główny Urząd Statystyczny. Warszawa: GUS.

Kowalczuk, I. (2012a). Stan i perspektywy rozwoju rynku usług gastronomicznych. In: Usługi w Polsce 2009-2011. Warszawa: Wydawnictwo IBRKiK (pp. 237-251).

Kowalczuk, I. (2012b). Zachowania konsumentów na rynku usług gastronomicznych - aspekt marketingowy. Warszawa: SGGW (p. 94).

Kwiatkowska, E., Levytska, G. (2008). Zachowania konsumentów na rynku nowoczesnych centrów handlowych. Zeszyty Naukowe SGGW - Ekonomika i Organizacja Gospodarki Żywnościowej. 71: 147-156.

Levytska, G., Kowrygo, B. (2007). Znaczenie usług gastronomicznych w żywieniu ludności w Polsce. Roczniki PZH. 58 (1): 371-376.

Masłowski, A. (2001). Rynek usług gastronomicznych: uwarunkowania i kierunki rozwoju. Warszawa: IRWiK.

Meyer, B. (2008). Ekonomika turystyki i rekreacji. Warszawa: Wydawnictwo Naukowe PWN (pp. 13-15).

Oksiński, M. (2012). Restauracje w stabilnej sytuacji. Nowości Gastronomiczne, Wydanie specjalne: Rynek Gastronomiczny w Polsce 2012. 1: 4.

Rosa-Wojnicka M. (2012). Polski rynek gastronomiczny w obliczu zawirowań gospodarczych. In: Konferencja Food Business Forum, Warszawa 27.09.2012.

Sala J. (2004). Marketing w gastronomii. Warszawa: PWE.

Rocznik Statystyczny Rzeczypospolitej Polskiej (1960-2014). Warszawa: Główny Urząd Statystyczny, GUS.

Tu, Y.T., Lin, S.Y. \& Chang, Y.Y. (2011). Relationships among Service Quality, Customer Satisfaction and Customer Loyalty in Chain Restaurant. Information Management and Business Review, 3 (5): 270-272.

Wang, C.H. (2012). The relationship of full-service restaurant attributes, evaluative factors and behavioral intention. International Journal of Organizational Innovation, 5 (2): 248-249.

Cite this article aS: Kowalczuk, I., Czarniecka-Skubina, E. (2015). Eating out in Poland: history, status, perspectives and trends.

Szczecin University Scientific Journal, No. 883. Service Management, 16 (2): 75-83. 
